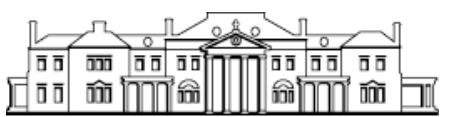

Levy Economics Institute of Bard College

Working Paper No. 716

\title{
Measuring Macroprudential Risk through Financial Fragility: A Minskyan Approach
}

\author{
by \\ Éric Tymoigne \\ Levy Economics Institute of Bard College
}

April 2012

The Levy Economics Institute Working Paper Collection presents research in progress by Levy Institute scholars and conference participants. The purpose of the series is to disseminate ideas to and elicit comments from academics and professionals.

Levy Economics Institute of Bard College, founded in 1986, is a nonprofit, nonpartisan, independently funded research organization devoted to public service. Through scholarship and economic research it generates viable, effective public policy responses to important economic problems that profoundly affect the quality of life in the United States and abroad.

\author{
Levy Economics Institute \\ P.O. Box 5000 \\ Annandale-on-Hudson, NY 12504-5000 \\ http://www.levyinstitute.org
}

Copyright (C Levy Economics Institute 2012 All rights reserved

ISSN 1547-366X 


\begin{abstract}
This paper presents a method to capture the growth of financial fragility within a country and across countries. This is done by focusing on housing finance in the United States, the United Kingdom, and France. Following the theoretical framework developed by Hyman P. Minsky, the paper focuses on the risk of amplification of shock via a debt deflation instead of the risk of a shock per se. Thus, instead of focusing on credit risk, for example, financial fragility is defined in relation to the means used to service debts, given credit risk and all other sources of shocks. The greater the expected reliance on capital gains and debt refinancing to meet debt commitments, the greater the financial fragility, and so the higher the risk of debt deflation induced by a shock if no government intervention occurs. In the context of housing finance, this implies that the growth of subprime lending was not by itself a source of financial fragility; instead, it was the change in the underwriting methods in all sectors of the mortgage markets that created a financial situation favorable to the emergence of a debt deflation. Stated alternatively, when nonprime and prime mortgage lending moved to asset-based lending instead of income-based lending, the financial fragility of the economy grew rapidly.
\end{abstract}

Keywords: Debt Deflation; Minsky; Financial Fragility; Systemic Risk

JEL Classifications: E12, E32, E44 


\section{INTRODUCTION}

Over the past decade, economists have progressively recognized that macroprudential analysis is an important tool for financial regulation and supervision. In the United States, the Financial Stability Oversight Council (FSOC) established by the Frank-Dodd Act is in charge of "identifying threats to the financial stability of the United States," and so needs to develop a comprehensive framework to understand and measure financial fragility.

This paper aims at contributing to the development of this framework by using the analytical framework of Hyman P. Minsky. The latter conceptualized the degree of financial fragility of an economic unit via three categories-Hedge finance, Speculative finance, and Ponzi finance. At the macroeconomic level, each category reflects a propensity of financial problems to generate a debt deflation process, with Ponzi finance reflecting a high risk of debt deflation.

Several authors have already used Minsky's analysis to develop indicators of financial fragility. This paper contributes to that research program by developing an index of financial fragility for housing finance in the United States, the United Kingdom, and France. In order to do so, a clear difference is made between bubble and Ponzi finance, and some emphasis is put on refinancing practices. This paper also contributes to the measurement of macroprudential risk by complementing the existing literature that has been focused on measuring the risk and size of financial disturbances like default or liquidity problems. Instead, the index focuses on the risk of amplification of a disturbance by analyzing the interaction between asset prices and debt during periods of economic expansion. In this case, financial fragility will grow, given credit and liquidity risks, if underwriting procedures change in such a way that a greater emphasis is put on refinancing and asset liquidation to service debts. Ponzi finance is a state of credit that is highly reliant on such a means to service debts.

This paper shows that financial fragility in housing finance started to grow from the late 1990s in the United Kingdom and the United States, and rapidly grew after the 2001 recession in the United States. France did not have as loose housing finance practices and so did not record an increase in financial fragility until the second part of the 2000s. The paper also provides a road map for future research on the construction of indexes of financial fragility. Notably, better datasets should be developed to measure the refinancing needs of different sectors of the economy and the prevailing underwriting practices in the financial sector. 
The first part of the paper defines financial fragility and briefly reviews the work that has been done in the context of Minsky's framework. The second part of the paper presents the methodology used to develop the index. The third part of the paper presents the index for the household sector. The fourth part suggests some extension, and the final part concludes.

\section{MEASURING FINANCIAL FRAGILITY: DEFINITION, PURPOSE, AND REVIEW}

\section{Defining Financial Fragility}

In order to develop a financial fragility index, one must have a conceptual definition of what is being measured. In this paper, we use the Minskyan conception of financial fragility, which is broadly defined by Minsky in the following way: "The robustness or fragility of the financial system depends upon the size and strength of the margins of safety and the likelihood that initial disturbances are amplified" (Minsky 1986, 209).

The overall fragility-robustness of the financial structure, upon which the cyclical stability of the economy depends, emerges out of loans made by bankers. [...] An emphasis by bankers on the collateral value and the expected values of assets is conducive to the emergence of a fragile financial structure. [...] One measure of the riskiness of financial instruments is the expected source of the funds that are needed to fulfill financial contracts. (Minsky 1986: 234-236)

The source of the disturbance can be default, rising interest rate, disruption in refinancing sources, a natural disaster, or any other "shocks" that affect either the cash inflow or cash outflow of an economic unit. While a lot of work has been done to identify the sources of disturbance (especially credit risk and liquidity risk), the goal in this paper is to focus on the risk of amplification of the shock induced by underwriting practices. In the Minskyan framework, this amplification goes through a snowball effect between asset prices and debt that, if left unchecked, leads to a debt deflation.

In order to more carefully measure the risk of debt deflation, Minsky made a difference between three different degrees of financial fragility induced by indebtedness: Hedge finance, Speculative finance, and Ponzi finance. Hedge finance means that an economic unit is expected to be able to pay its liability commitments with the net cash flow it generates from its routine economic operations (work for most individuals, going concern for companies) and monetary balances. Thus, even though indebtedness may be high (even relative to income), an economy in which most economic units rely on Hedge finance is not prone to a debt deflation-unless unusually large declines in routine cash inflows and/or unusually large increases in cash 
outflows occur. Even then, cash reserves and liquid assets are expected to be a large enough amount to provide a buffer against unforeseen problems.

Speculative finance means that routine net cash flow sources and cash reserves are expected to be too low to pay the capital component of liabilities (principal service, margin calls and others). As a consequence, an economic unit needs either to borrow funds or to sell some less-liquid assets to pay liability commitments. This state of financial fragility is especially common among economic units, like commercial banks, whose business model involves funding the ownership of long-term assets with short-term external sources of funds. As a consequence, they require constant access to reliable refinancing sources to work properly.

Ponzi finance means that an economic unit is not expected to generate enough net cash flow from its routine economic operations $\left(N C F_{O}\right)$, nor to have enough monetary assets to meet the capital and income services due on outstanding financial contracts $(C C)$. At time 0 , it is expected that the following applies until a date $n$ :

$$
E_{0}\left(N C F_{O t}\right)<E_{0}\left(C C_{t}\right) \forall t<n
$$

Note that this implies that Ponzi finance involves what Minsky called (defensive) positionmaking operations, i.e., refinancing and asset liquidation for the purpose of servicing debts. More precisely, Ponzi finance relies on an expected growth of refinancing loans $\left(L_{R}\right)$, and/or an expected full liquidation of asset positions at a growing asset price $\left(P_{A}\right)$ in order to meet debt commitments on a given level of outstanding debts $(L)$ :

$$
E\left(N C F_{P M}\right)=\Delta L_{R}+\Delta P_{A} Q_{A}>0 \text { and } \Delta\left(E\left(C F_{P M}\right) / L\right)>0
$$

At the macroeconomic level, if a critical portion of economic units is involved in Ponzi finance, the economic system is highly prone to debt deflation. As Minsky put it: "An increase in the ratio of Ponzi finance, so that it is no longer a rare event, is an indicator that the fragility of the financial structure is in a danger zone for a debt deflation" (Minsky 1986, 379). Thus, a high reliance on net cash flow from position-making operations on the macroeconomic level is what amplifies an initial disturbance. Without this reliance on the capacity to refinance or sell assets, the impact of defaults and other disturbances will be contained, and limited government involvement will be needed to promote financial stability.

Leaving aside fraud, Hedge, Speculative, and Ponzi finance must have a positive expected present value to be implemented; otherwise an honest banker would not consider lending. The main difference between them is based on the reliance on position-making 
operations to create a positive net worth. Hedge finance is not expected to require any positionmaking operation; Ponzi finance is expected to require growing position-making operations. Moreover, whereas at the individual level the choice between refinancing and liquidation is a matter of relative cost, at the aggregate level the latter portfolio operation is impossible, and so it is an abnormal source of cash inflows (Minsky 1962):

As an empirical generalization, almost all financial commitments are met from two normal sources of cash: income flows and refinancing of positions. For most units - especially those that have real capital goods at their assets - the selling out of their position is not feasible (no market exists for a quick sale); for others, aside from marginal adjustments by way of special money markets, it is an unusual source of cash. [...] Financial instability occurs whenever a large number of units resort to extraordinary sources for cash. (Minsky 1972, 105)

Given that the index constructed below is an aggregate index concerning the risk of debt deflation, the liquidation of non-liquid assets is considered an abnormal source of fund, so the reliance on this source of cash to meet debt services increases financial fragility.

As the second quote at the beginning of this section suggests, another way to understand the $\mathrm{H} / \mathrm{S} / \mathrm{P}$ classification is in terms of the underwriting characteristics underlying each scheme.

Loans based on the value of pledged collateral are different in kind from loans based on the value of the cash flows that are expected from income-earning operations. True, in structuring a loan that is mainly based on prospective cash flows the loan officers may insist on a margin of safety in the form of pledged collateral. But this would not be the primary consideration [...]. The viability of loans mainly made because of collateral, however, depends upon the expected market value of the assets that are pledged. [...] Thus, the overall fragilityrobustness of the financial structure, upon which the cyclical stability of the economy depends, emerges out of loans made by bankers. [...] An emphasis by bankers on the collateral value and the expected values of assets is conducive to the emergence of a fragile financial structure. (Minsky 1986, 233)

Hedge finance involves income-based lending, that is lending in which the creditworthiness of a borrower is heavily reliant on its operational income. Collateral may still be used to determine the profitability of a loan, but its role is to protect a bank against unexpected credit events, not to be the expected source of debt servicing.

Ponzi finance involves, partially or fully, asset-based lending, that is, lending based on the expected price of assets. More precisely, income-based Ponzi finance involves financial contracts that contain a period of time during which rising refinancing is needed to cover debt services until operational income is high enough to cover debt services. Minsky always 
emphasized that capital equipments with a long period of maturation may involve such Ponzi financing. Asset-based Ponzi finance, also called a pyramid scheme, contains underwriting expectations such that operational income will never be high enough to service debts. The only means to generate a positive net worth is to sell assets at a price high enough to cover debt payments and generate a profit.

Note that this categorization is not a measure of the use of external funding, i.e., of the size of leverage, but rather a measure of the quality of the leverage. The latter is measured by focusing on the means used by debtors to service debts. Indeed, it is not because the ability to pay is high (low credit risk) that financial fragility is low-because low credit risk may be possible only if refinancing sources stay open and asset prices continuously rise. This is what we observed during the past financial crisis, when both prime and non-prime borrowers relied on rising home prices to sustain their rising indebtedness. Similarly, low ability to pay (high credit risk) may not be a major source of instability - if this high credit risk is mainly based on income rather than refinancing and asset sales. For example, subprime mortgages have a much higher probability of default than prime mortgages, but they are not a major concern if underwriting is done properly to verify income, cash reserves, and jobs and if enough collateral is sought by banks.

\section{Purpose of Measuring Financial Fragility}

The need for a conceptual framework that explains and measures financial fragility has been illustrated very clearly during the housing boom. From at least 2004, most households and financial institutions were engaged in mortgage practices that involved negative amortization, expectations that refinancing at low interest rate would be available to service debts, underwriting based on rising home prices, and other practices that contributed to a higher risk of debt deflation. During the housing boom, all this, as well as fraud, was the common practice across the board in the mortgage industry — so much so that 50 percent of the purchase mortgages that originated in 2006 were low-doc and no-doc loans (Wray 2009; Black 2009). The growth of this type of loan was the highest in prime loans from 2001 to 2006 (Zelman 2007).

However, household net worth was rising, bank profits were high, and default rates recorded historical lows, which seemed to indicate a robust economy. For example, in 2004, Greenspan argued that the rapid growth of household debt was not a problem because their net 
worth was also rising. However, low default rates and high profits were only possible because of the loose underwriting standards in all segments of the mortgage industry. For example, the proportion of payment-option mortgages grew dramatically from almost 0 percent in 2003 to 25 percent of all non-prime mortgages by the end of 2005 (Federal Deposit Insurance Corporation 2006). This allowed households to pay only part of the interest and none of the principal for a few years, thereby making it easier to service the mortgage until it recasted.

If regulators had a means to recognize changes in funding practices that promote financial fragility, it would provide them with a signal that maybe low default rate and rising profitability are not necessarily a sign of financial health/strength, and that some interventions may be needed to curtail financial practices that promote financial instability. This may involve intervening long before a recession is in sight and even if there is no bubble. All this is, of course, pretty typical of the way regulators intervene, but it is worth emphasizing a bit more because it is critical for effective regulation and supervision.

Firstly, the point of detecting financial fragility is not to detect financial crises or economic recessions, but rather to intervene proactively to prevent crises from occurring, or at least limit their significance. There is a large body of literature that focuses on developing early warning systems for financial crises (Galati and Moessner 2010). Ultimately, the search for these systems has not proven terribly successful for at least two reasons. First, when an economy is financially fragile, there are many different sources of disturbances that can be very complex and/or impossible to measure because of lack of data. More importantly, even usual fluctuations in income, asset prices, and other variables can lead to a crisis, and the triggering of a crisis can be based on unpredictable changes in the mood of economic agents. As Bell (2000) notes, most banking crises involve, at least in part, random triggers that are impossible to predict. Thus, rather than focusing on predicting the size or timing of financial crises (something probably impossible to do), a more productive analysis should focus on the growth of financial fragility during periods of economic stability. Second, significant economic and financial crises do not just happen; there is a long process during which the economic and financial system becomes more fragile. The point of detecting financial fragility is to provide a means to capture the process of fragilization so regulators can intervene before problems accumulate to the point that debt deflation becomes likely. More broadly, by measuring financial fragility, one puts the reliance on underwriting and refinancing practices on the radar screen of regulators - something that they have had a tendency to ignore. 
Secondly, the point of detecting financial fragility is not to detect asset-price bubbles. Indeed, the three degrees of financial fragility are defined independently of the accuracy of the asset pricing mechanism. Ponzi finance does not require the existence of a bubble (i.e., that $P_{A}$ be above its "fundamental" value, however defined); it just requires rising prices of collateral or other assets held by the entity involved in a Ponzi process. The latter condition is required for cheap refinancing to occur and/or to liquidate at a price that covers debt services. More broadly, for Ponzi finance to occur, net worth should be rising, but that does not tell us anything about the existence of a bubble. This is, however, not a problem because this is not what financial fragility aims at detecting; the aim is to detect debt deflation risks that result from the interaction between debt and asset value on the upside. Thus, an economy may be highly fragile even if there is no bubble, and a bubble may exist, but financial fragility may be limited because of the limited recourse to external funding. In that case, a debt deflation is not possible given that debt is not involved, or is of limited size. An example of this would be the current housing bubble in China, which is mostly self-funded.

\section{A Brief Review of Past Work}

A more substantial review of the measure of financial fragility and discussion of macroprudential risk is available elsewhere (Galati and Moessner 2010; Schroeder 2008, 2009). This section focuses briefly on the papers that have used Minsky's theory to develop a measure of financial fragility. Several studies have been conducted in this framework of analysis, and they can be separated into two categories. The most straightforward studies analyze the trend of several variables and check how they help to explain recessions. The second set of studies uses the Hedge, Speculative, and Ponzi categories, and aims at detecting one or more of these categories.

In the first set of studies, authors usually find that leverage increases and liquidity decreases during periods of expansion (Minsky 1977, 1984, 1986; Sinai 1976; Niggle 1989; Wolfson 1994; Grabel 2003; Estenson 1987). Leverage and liquidity are measured by looking at several balance sheet ratios, like debt-to-income ratio, proportion of short-term debts, debt service-to-income ratio, and the proportion of cash and other liquid assets. In her study of the Great Depression, Isenberg $(1988,1994)$ finds that, instead of being recorded at the aggregate level, the fragilization of the economy can be localized within the most dynamic part of the nonfinancial business sector. In his own study of the Great Depression, Minsky (1984) notes that 
the non-financial business sector may not be at the source of the fragility, but rather the household sector or the government sector may be the main contributor to the risk of a debt deflation.

The second group of authors has developed a more elaborated strategy that aims at detecting the different stages of financial fragility. Some of them develop methods to detect all three stages (Schroder 2009; Foley 2003). Other authors focus their attention on detecting a specific stage of fragility like Ponzi finance (Seccarecia 1988) or an overall index of fragility that shows overall reliance on position-making operations (De Paula and Alves 2000). This paper contributes to this second group of studies.

\section{FINANCIAL FRAGILITY INDEX: CONSTRUCTION, INTERPRETATION, AND DATA ANALYSIS}

\section{Construction}

In order to construct the index, the theory presented above indicates that one needs data that reflect asset-based lending, refinancing needs, and debt burden. While the United States is, by far, the most data-rich country, an index can also be constructed for France and the United Kingdom by using similar data or constructing proxies. The latter two countries do not provide as much data partly because it is not available and partly because some of the lending practices existing in the US are marginal or inexistent. For example, revolving home equity lending was forbidden in France until very recently when Article 24 of the 2005 Confidence and Economic Modernization Act (Loi pour la confiance et la modernisation de l'économie) allowed the government to reform mortgage lending in order to introduce revolving home equity lending and reverse mortgages. The latter became legal in March 2006 via ordinance 2006-346, but have been marginal since that time (Lamoussière-Pouvreau and Masset-Denèvre 2007).

The index contains the following variables when available: home mortgage of households $(\mathrm{L})$, home price index $(\mathrm{P})$, mortgage-financial-obligation ratio or interest-obligation ratio (MOR), the proportion of home equity loans in all mortgages (HELOC), the cumulative value of home equity withdrawals (HEW), the proportion of cash-out refinance mortgages among refinance mortgages (COR), and the ratio of mortgage debt to monetary assets (MMR). The home price index was measured relative to the population of the country, and home mortgage was measured relative to the GDP of the country. 
Once the needed variables are obtained, the next step is to assign a weight to each of them. Minsky's framework gives us some clues about the ordinal importance of different variables to measure fragility, but does not provide any clue about their cardinal importance. Thus, some unavoidable arbitrariness exists in the weight assigned. Variables like debt service ratio, refinancing volume, and proportion of liquid assets relative to debts are assigned a greater weight because they more directly provide a clue about the reliance on position-making operations. However, the importance given to these variables depends also on how well the data reflect refinancing and liquidation needs. Thus, the weight given to a specific variable will vary in function of its importance relative to the definition of financial fragility and in relation to its reliability. This, of course, leaves some space for arbitrariness. In order to check the sensitivity of the index to changes in weights, the Appendix shows what the index would look like under different weight structures. The trend of the index is unaffected but its amplitude is.

Once the weights have been assigned, all variables are seasonally adjusted and the year 1996 is used as a base to calculate an index for all variables. Each index is then combined to calculate an index of financial fragility by weighing each variable. The theoretical weights are (see Appendix 1 for other weight structures):

$$
\begin{gathered}
I_{H F U S}=0.1 I_{L}+0.1 I_{P}+0.15 I_{C O R}+0.15 I_{H E L O C}+0.3 I_{M O R}+0.2 I_{M M R} \\
I_{H F U K}=0.15 I_{L}+0.15 I_{P}+0.2 I_{H E W}+0.25 I_{M O R}+0.25 I_{M M R} \\
I_{H F F}=0.15 I_{L}+0.175 I_{P}+0.175 I_{H E L O C}+0.275 I_{M O R}+0.275 I_{M M R}
\end{gathered}
$$

The index of home finance $\left(I_{H F}\right)$ is equal to 100 in the average for year 1996, which was a period of relative calm in the housing market for all countries and also the first year when data is available for house prices in France. MOR is the variable that more directly measures the debt burden, and so it is given a higher weight, but the total interest ratio is given a slightly lower weight because it is not specific to mortgage servicing. A higher weight is also given to MMR because it is able to capture more directly liquidation pressures. Finally, variables that measure refinancing needs and asset-based lending are given a total weight of 30 percent in the United States that is equally split between COR and HELOC.

The main idea behind the index is that the risk of debt deflation grows as a result of a combination of factors, namely rising debt burden, rising refinancing needs, and rising assetbased lending. The section focusing on the data analysis will expand on this idea. 


\section{Interpretation}

At the macroeconomic level, financial fragility will grow over time because of three effects: the compounding effect, the volume effect, and the interconnectedness effect. Compounding effect refers to the length of time economic units have been involved in Ponzi finance. As the length of time increases, refinancing needs and liquidation needs grow because the size of interest payments due grows exponentially. The volume effect refers to the fact that as more economic units are involved in Ponzi finance, financial fragility grows given the time during which Ponzi finance was used. Together, they increase the interconnectedness of economic units as growing refinancing and liquidation needs are required, and so economic units become more dependent on a smooth functioning of financial markets. Therefore, the longer and more widely Ponzi finance is used, the more destructive a debt deflation will be if it occurs. Government intervention may prevent a debt deflation from occurring, but the more Ponzi finance is used, the larger the intervention will have to be, and so the more costly it will be. In addition, a long period of Japanese-style stagnation may follow.

The goal of the index is to capture those effects by capturing changes in funding methods that promote financial instability. Following Minsky's framework, during periods of economic stability, financial fragility grows and the closer we get to a crisis, the more this growth accelerates, as more economic units use Ponzi finance and as the duration of the Ponzi finance increases. When a crisis occurs, the use of Ponzi finance stops, asset liquidation and debt cancelation grow rapidly, and ultimately a debt deflation emerges if nothing is done to stop it. During a crisis, financial fragility will start to decline as economic units try to settle their debts.

\section{Limits}

There are conceptual and data limits to the index. In terms of data, the most obvious one is that the index is as reliable as the variables and weights used. As shown below, there are intrinsic limits to the data that have been chosen, which limits their capacity to detect the risk of amplification through rising debt burden and the reliance on refinancing and asset-based lending. The variables chosen are proxy macroeconomic variables that may overestimate or underestimate actual risks. In addition, as explained above and in the Appendix, there is some arbitrariness involved in choosing the weights that affect the amplitude, but not the direction, of the index. 
In terms of concept, one must remember that Ponzi finance involves expectations. This is important because it does not mean that right now there is a need to refinance or liquidate in order to meet cash commitments. In addition, this state of expectation may never materialize if net cash flows from core operations turn out to be higher than expected, and/or interest rates turn out to be lower than expected, and/or borrowing for a longer maturity than expected is available. In fact, the frustration of expectations is part of the internal dynamics of the financial instability hypothesis. However, if the state does materialize itself and position-making operations are actually used, the index will capture them.

The fact that expectations are involved has two implications for empirical analysis. A first implication is that Ponzi financial practices will be going in on underwriting procedures before they are captured in actual data about refinancing operations, debt levels, and other variables (Kregel 1997; Suzuki 2005; Knutsen and Lie 2002). Thus, macroeconomic data will tend to capture the development of financial fragility with a delay. In order to deal with this issue, it is therefore important to check how loan underwriting is done, i.e., traditional bank supervision is crucial. Indeed, at the level of each bank, one can understand the nature of the expectations behind the growth of debt and the nature of a Ponzi process, if existent. Two central questions to ask at the microeconomic level are: (1) will debts be repaid (expected default rate and recovery rate), and (2) how will repayment of debts occur (sources of cash flows for repayment and amount of defensive-position making operations needed)? As Minsky (1975) noted decades ago, this second question is not asked by current banking supervisors, who mostly focus on detecting fraud and mismanagement.

\section{Data Analysis}

For households, the net cash flow from operations is their disposable labor income and financial earnings less living expenses necessary to maintain their current standard of living. This net cash flow needs to be compared to mortgage debt services to get a primary idea of financial fragility in housing finance. A dataset that comes close to compare the two cash flows is the mortgage debt service ratio, which is available in the United States, but not in France or the United Kingdom. The Federal Reserve Board publishes quarterly data that is shown in Figure 1, and the ratio is defined as mortgage debt service over after-tax income. For the two other countries, the mortgage debt service ratio can be proxied, albeit quite imperfectly, by the interest-obligation ratio on all debts, that is, the ratio of interest payments on all debts relative to 
disposable income. The most significant debt among households is their mortgage, so the dynamic of the interest-service ratio is highly influenced by this specific debt. However, this dataset cannot capture the burden induced by the servicing of the principal.

Figure 1 Debt service ratio, percent

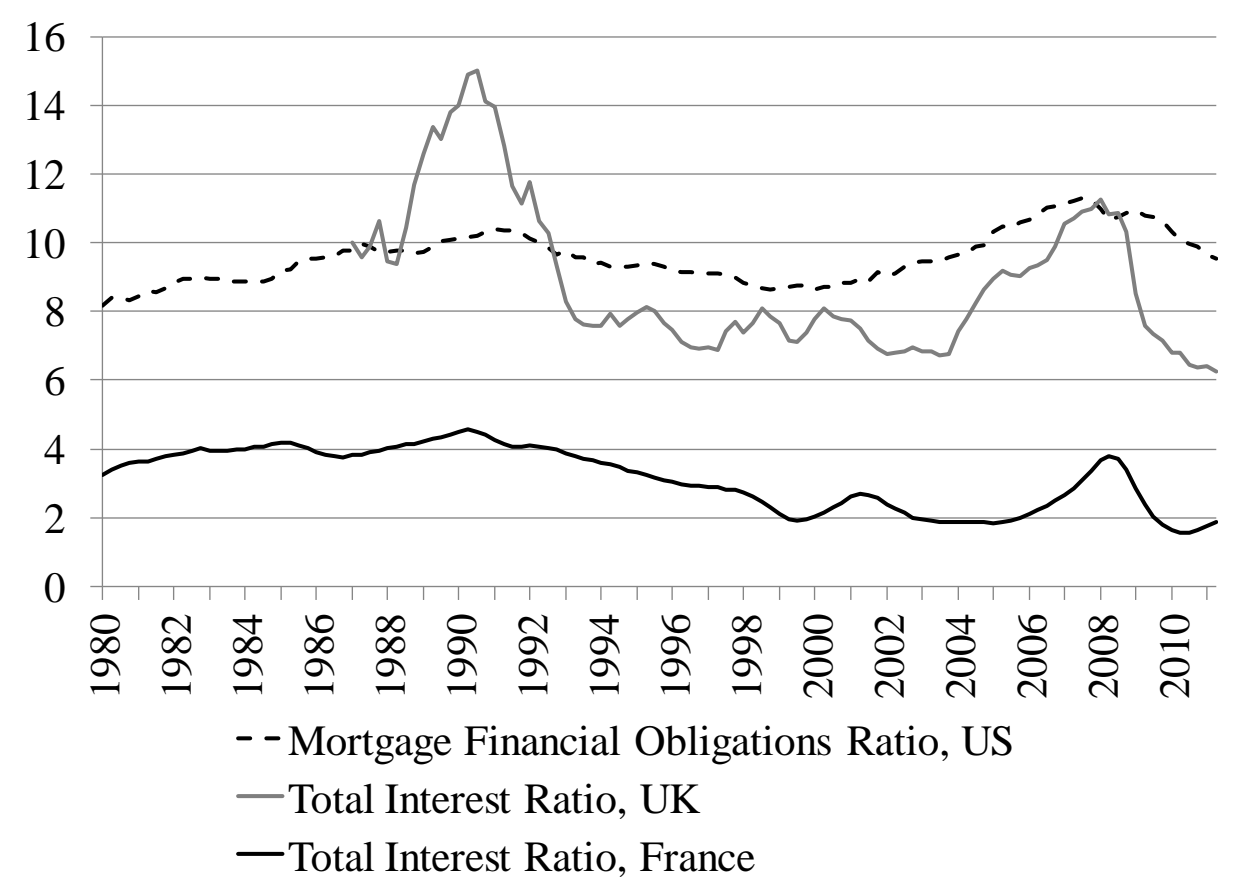

Source: Federal Reserve Board (FRB), Office for National Statistics (ONS), Institut national de la statistique et des études économiques (INSEE).

Note: The homeowner mortgage financial obligation ratio includes payments on mortgage debt, homeowners' insurance, and property taxes.

The main feature of this data is that the household sector never seems to engage in Ponzi finance because the cash flow condition is never verified, i.e., the ratio is never greater than 100 percent. In addition, there are several limitations to the debt service ratio for our purpose (Dynan, Johnson, and Pence 2003). One of the main limits is that it is a measure of actual cash flow ratio, rather than a measure of expected cash flow ratio. As a consequence, financial fragility will be captured with a delay, and does not capture the motivation or cause behind the growth of debt service:

Some households may increase their ratios by borrowing more because they are appropriately optimistic about their future income prospects and their corresponding ability to repay debt. Other households may increase their ratios because they have suffered an unanticipated misfortune that necessitates borrowing to cover their extra expenses. An increase in the DSR indicates good 
news for the economy in the first example and bad news in the second. (Dynan, Johnson, and Pence 2003, 417-418)

These limitations of the debt service ratio imply that the data cannot be used directly to measure financial fragility. Instead, a rising ratio will be of concern if it occurs simultaneously with other financial trends. Indeed, two central features of financial fragility are that refinancing for the purpose of servicing debts grows and liquidity buffers shrink; therefore, rising debt service ratios together with declining liquidity ratios and growing refinancing needs provide a better indicator of rising financial fragility at the macroeconomic level.

Regarding liquidity buffers, the amount of monetary assets relative to the amount of debts has decreased dramatically over time in all countries. Figure 2 shows that US households used to have almost twice as many monetary assets as mortgage debts in the middle of the 1980s. By the end of the 2000s they held as many monetary assets as their outstanding mortgage debt. Similar trends occurred in France and the United Kingdom. Thus, the capacity of households to respond to a situation in which operational income is insufficient to meet debt services has decreased dramatically, creating a greater dependence on defensive positionmaking operations.

Figure 2 Monetary assets relative to mortgage debt of households

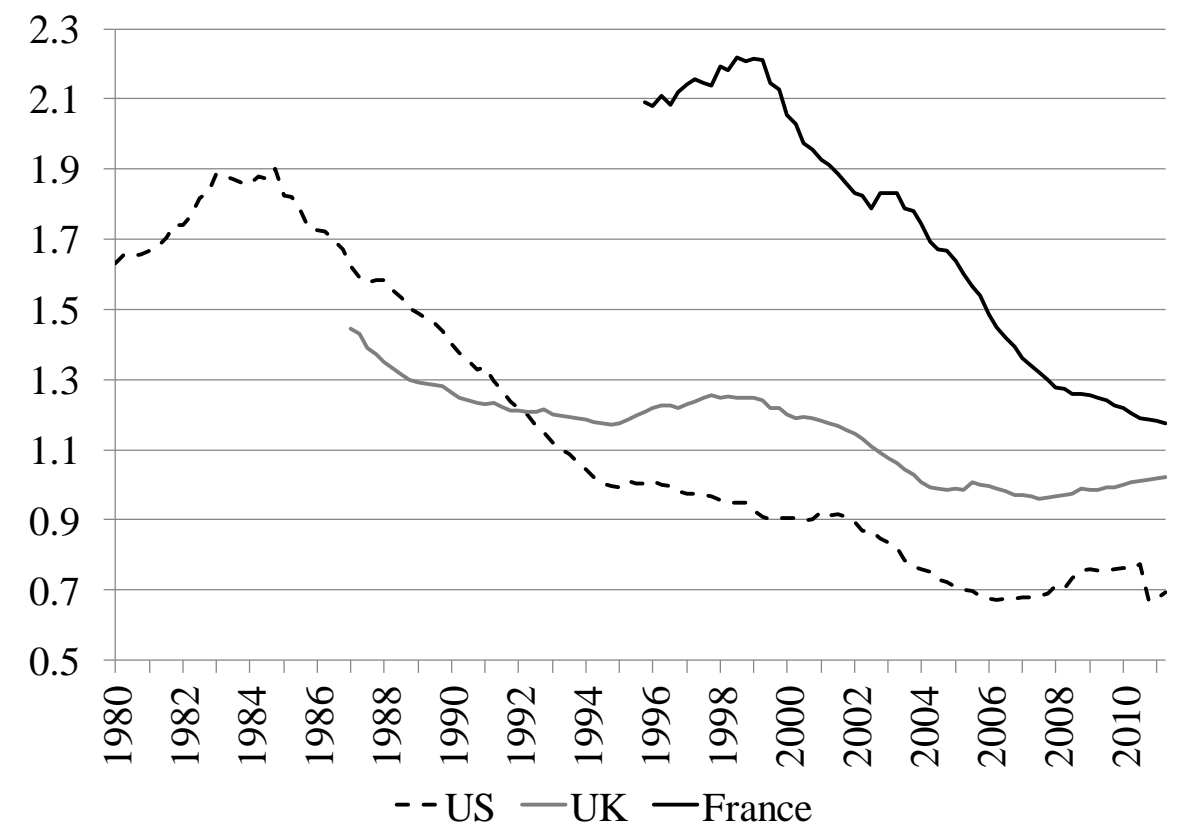

Source: FRB, ONS, INSEE. 
In the Index, the inverse of this ratio is used to make sure that all variables move in the same direction to indicate the same change in financial fragility.

Regarding refinancing operations, in the United States, the Federal Home Loan Mortgage Corporation and the Financial Housing Finance Agency provide datasets about mortgage refinance. Figure 3 shows that, from the early 2000s, the amount of refinance mortgages, either to lower cost (term rate refinance) or to extract cash (cash-out refinance), usually has represented the majority of mortgage originations. Within refinance mortgages, term rate refinance usually represents the main cause of refinancing except in the mid-2000s when cash-out refinance dominates.

For our purposes, the most interesting refinancing datasets are those that relate to the growth of asset-based underwriting because they provide a glimpse of the change in the expectations underlying mortgage funding. A rapid growth in term rate refinance does not provide such a signal because it may rise only once payment difficulties have materialized and/or because rates are lower and mortgagors find it profitable to refinance. Thus, term rate refinance does not provide a clue about financial fragility, or it does so only once the problems have began to accumulate beyond repair, which is what was observed during the Great Recession. In addition, term rate refinance does not provide a clue that asset-based lending is rising, while cash-out refinance does. From the middle of 2004, cash-out refinance mortgages represented the majority of refinance mortgages, and their proportion peaked at about 70 percent of all refinance mortgages. One may observe that from 1999, their proportion also grew rapidly and reached about 55 percent in 2000 right before the 2001 recession; however, purchase mortgages represented about 70 percent of mortgages originated in 1999 and 2000. 
Figure 3 Proportion of refinance mortgage origination in all mortgages and share of cash-out refinance in refinance mortgages, United States, percent

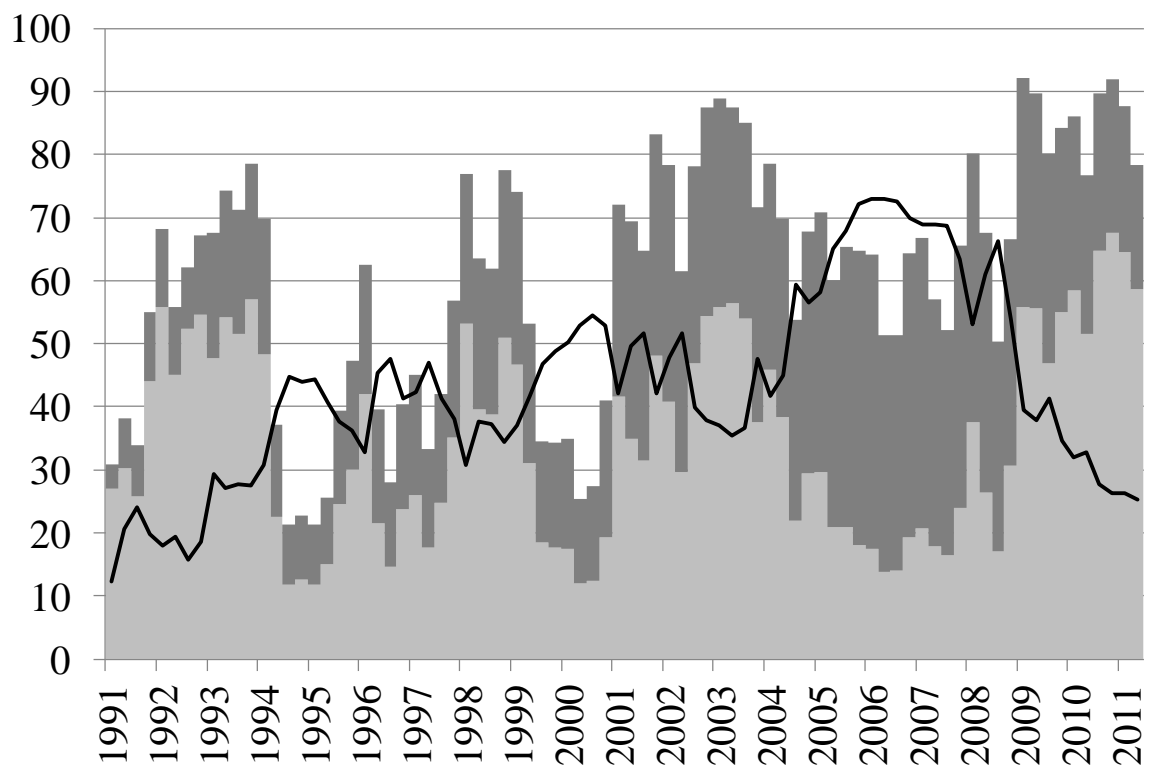

Rate-Term Cash-Out -Cash-Out Share of Refinances

Source: Financial Housing Finance Agency

The datasets available about cash-out refinancing are of limited scope because they relate mainly to conforming mortgages that are overwhelmingly prime mortgages. This means that a good part of the growing fragility going on in the 2000s cannot be captured through this data; however, even the prime mortgage business in the US became dependent on positionmaking operations, with a high reliance on low-doc mortgages and expectations that home prices would continue to rise. Moreover, similar to the debt service ratio, the motivations underlying the trend of cash-out refinancing are unknown. While the cash extracted may be used to repay other debts, it may also be used for other purposes like home improvements or vacations.

The Federal Reserve provides a complementary dataset about asset-based lending in housing that records the outstanding amount of revolving home equity loans. Figure 4 shows the proportion of revolving home equity in all mortgages. 
Figure 4 Proportion of revolving home equity loans in outstanding mortgages in the United States

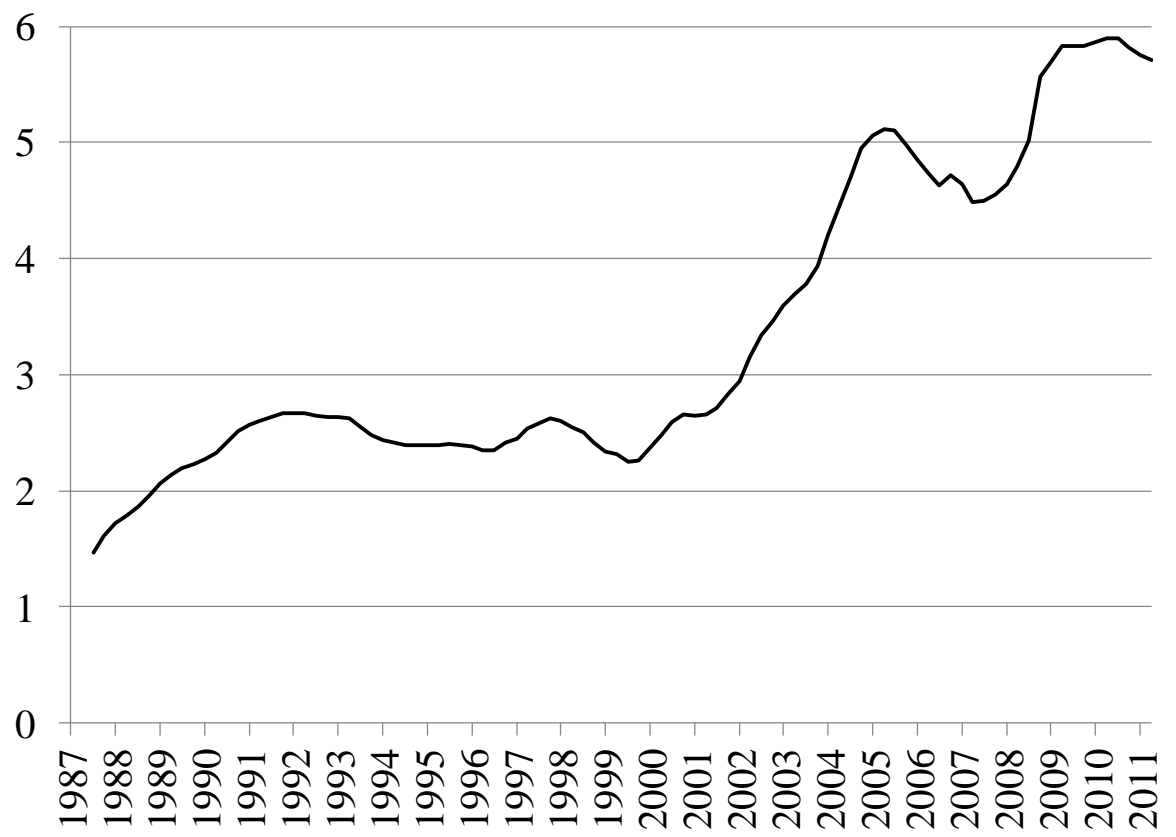

Source: Federal Reserve Board

This dataset provides a somewhat similar picture as the proportion of cash-out refinance. Both datasets suggest a rapid increase in asset-based lending from the early 2000s. As explained above, home equity lending was nonexistent in France until 2006, and can be considered to be zero for the entire period during which the index is constructed. In the United Kingdom, home equity withdrawal provides an imperfect proxy for asset-based lending. Home equity withdrawal, a flow variable, measures the net change in the amount of home equity. Home equity is withdrawn when house equity declines (because home prices decline or mortgagerelated debts rise) and when someone sells a home. Given that first-time home buyers inject equity into the house and home sellers withdraw equity, and given that home sellers usually have more equity in the house than home buyers, home equity withdrawal is usually positive and closely follows the turnover in the housing market (Reinold 2011). Thus, home equity withdrawals may have nothing do with housing refinance even though it is positively affected by it. In addition, the data does not tell which type of refinancing affects equity withdrawals when cash-out refinance is really what matters to detect asset-based lending. Knowing the limit of the data, the cumulative value of the home equity withdrawals can help to measure financial fragility, and rising equity withdrawal means that a majority of homeowners either refinance or sell their home - possibly to repay their mortgages. Figure 5 shows home equity withdrawal and its cumulative value. Two periods stand out in the UK, the 1980s and the 2000s, which both 
recorded rapid increases in home equity withdrawals. Figure 6 shows the proportion of cumulative home equity withdrawal relative to all mortgages, which is the variable used in the index to provide a proxy for the relative importance of asset-based lending. This proportion was high in the mid-1980s and early 2000s

Figure 5 Home equity withdrawal, millions of sterling pound

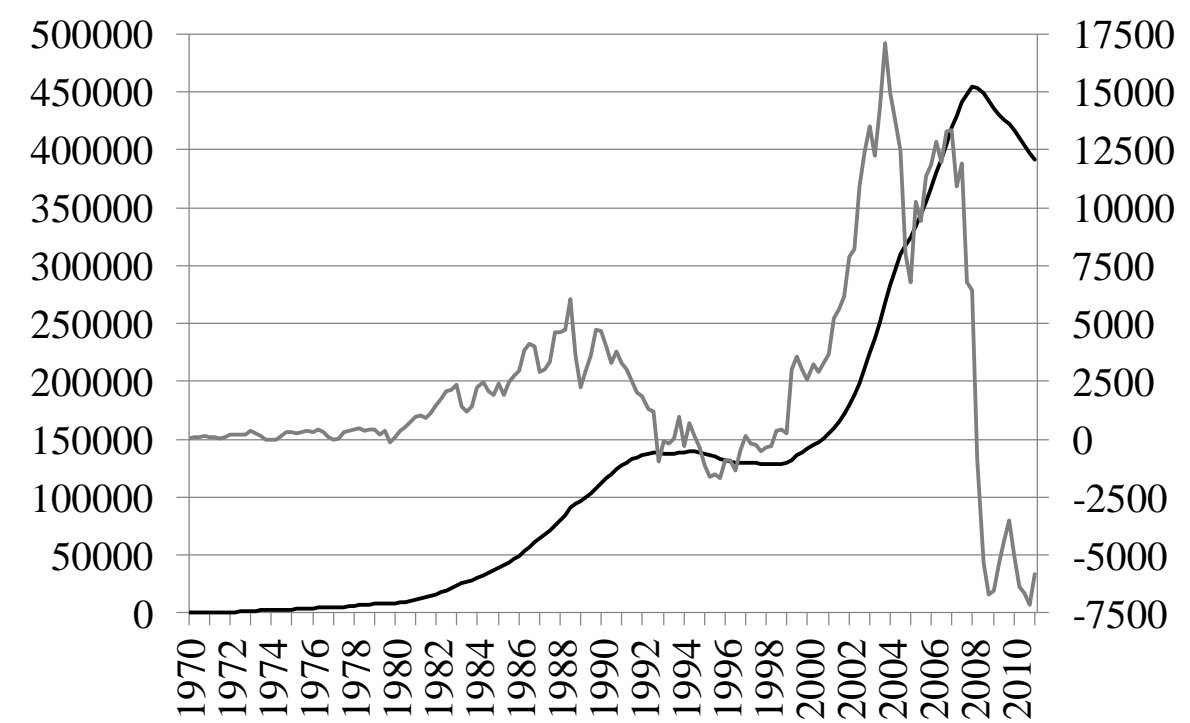

-Cumulative HEW (Left Axis)

- Home Equity Withdrawal (HEW)

Source: Bank of England

Figure 6 Ratio of cumulative HEW to mortgages

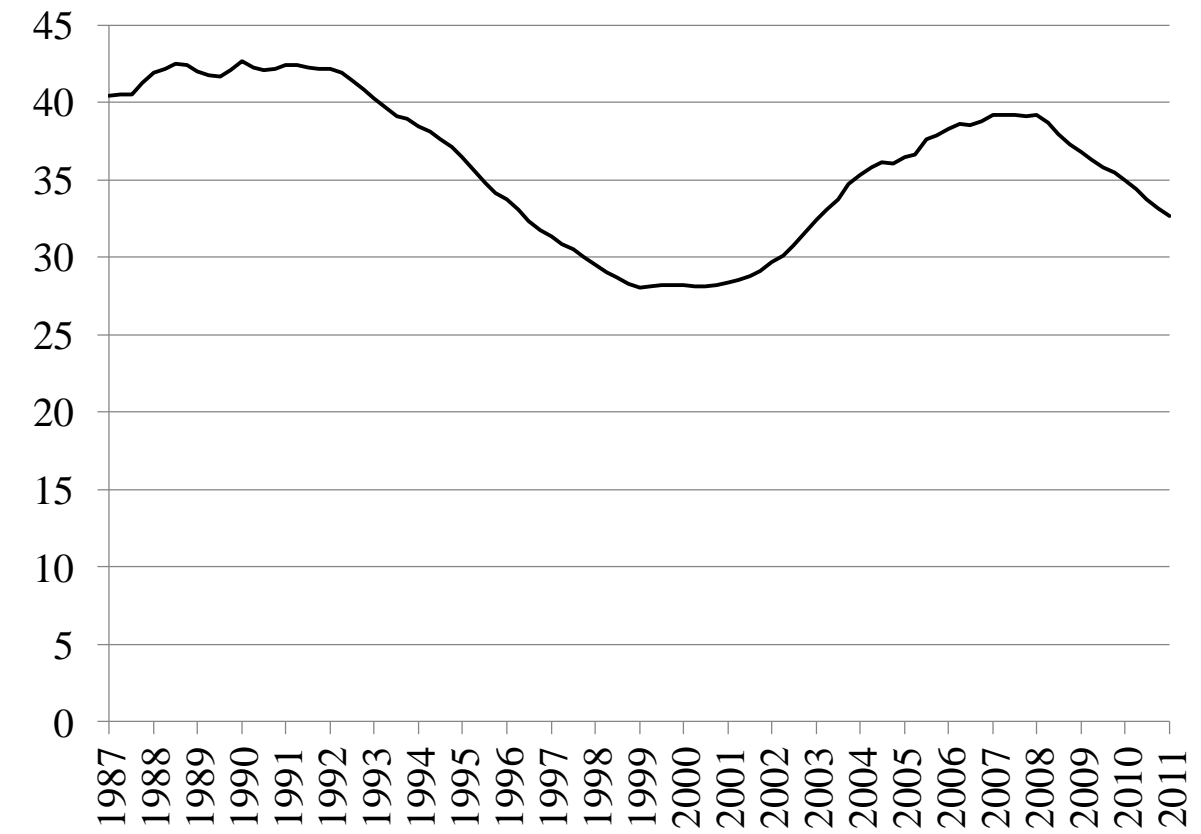

Sources: Bank of England, Office for National Statistics 
Again, the datasets do not provide a direct observation of the motivations behind the change in home equity withdrawals; some people may sell their home because they have to repay an unaffordable mortgage, others just want to rent instead of own or may have other reasons. Thus, like for all other datasets, instead of looking at the data in isolation, it should be compared with other signs of financial fragility.

Finally, the index of financial fragility requires some data about how the underlying collateral or asset used to sustain an economic activity behaves. In the case of residential home mortgages, the measurement of financial fragility relies partly on how home prices behave overtime. For asset-based lending to thrive, collateral value must be rising (if a long position is taken, which is the case for housing), so a period during which the outstanding volume of mortgages and home prices rise simultaneously is a necessary but not sufficient indicator of growing financial fragility. Figure 7 shows that, in the United States, home prices grew tremendously from the late 1990s and dropped rapidly in the second part of the 2000s. Similar trends were observed in the United Kingdom.

Figure 7 Home price indexes (Base year: 1996)

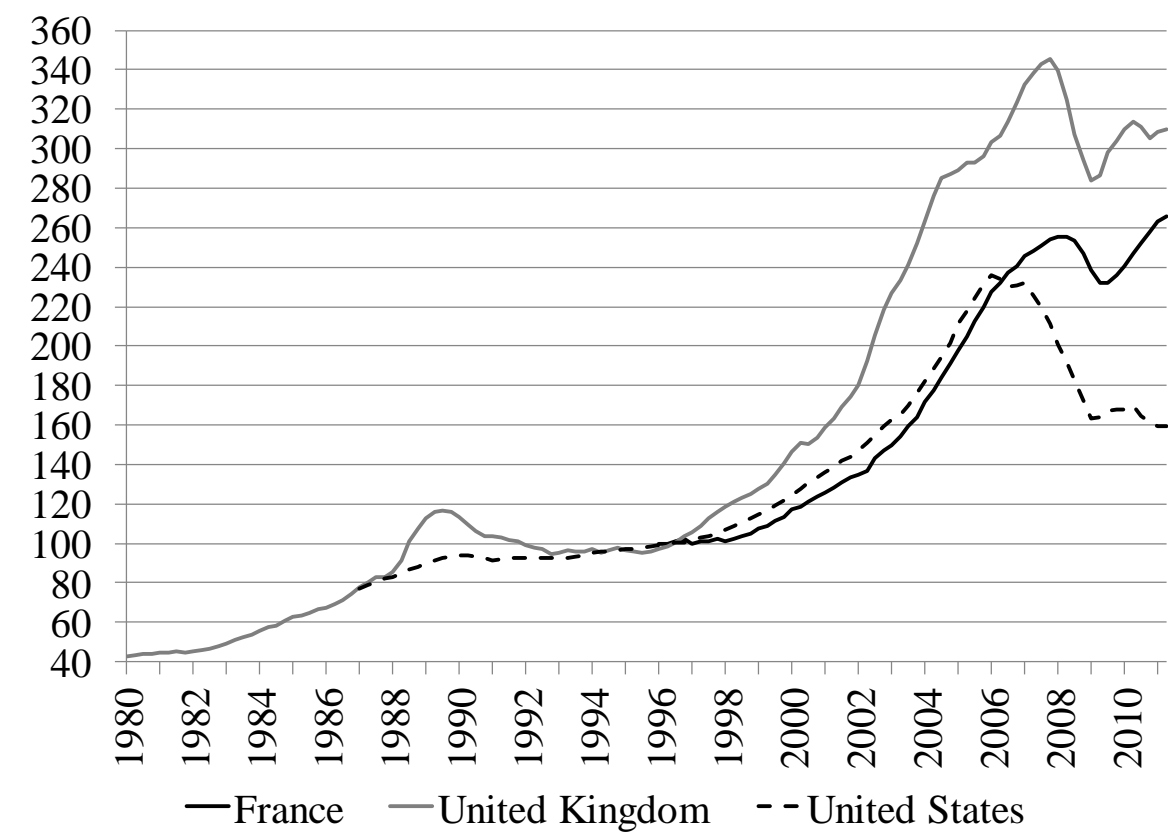

Sources: Standard and Poor's, Nationwide, INSEE

This overview of each individual variable shows that they all have some limits for the purpose of measuring financial fragility. For our purpose, the main limit may be that the motivations behind the behavior of each variable are unknown. However, by combining the 
datasets and looking at how they behave simultaneously, this paper argues that one can get an idea of the trend of financial fragility in house funding.

\section{THE INDEX OF FINANCIAL FRAGILITY IN HOUSING}

When combined together in the way presented above, the variables provide a view of how financial fragility has evolved relative to the base year of 1996, which is shown in Figure 8. All countries experienced a rapid increase in home prices in the first part of the first decade of the new millennium, however, financial fragility grew much less rapidly in France compared to the United States and the United Kingdom. A tighter mortgage regulation limited the capacity of French banks to underwrite mortgages on the basis of rising home prices instead of income. However, the financial fragility of France did rise by about 35 percent from 2005 to 2008, due to the combination of a decline in liquidity buffers, rising outstanding mortgages, rising home prices, and rising debt services relative to disposable income. Households owning a property in France did experience a brief decline in financial fragility from 2008 and 2009, but fragility seems to be on the rise again. Given that revolving home equity lending has been authorized, unless underwriting standards stay strong, one may expect a rapid increase in the financial fragility of French households if the economic conditions become conducive.

In the United Kingdom, financial fragility in housing finance declined during the first half of the 1990s, but started to go back up again from the last quarter of the 1990s. Home prices grew very rapidly, as did mortgage lending, home equity lending (as proxied by home-equity withdrawal), and the debt service ratio. At the same time, the liquidity buffer of households declined, and the combination of all these trends made households more vulnerable to financial difficulties induced by unemployment, declines in home prices, rising interest rates, rising amortization rates, and decline in the availability of refinancing loans. As a consequence, financial fragility grew by almost 70 percent from 1996 to 2008 and about 50 percent from the early 2000s until 2008. The UK did not have any recession from the early 1990s to 2008, which provided a fertile ground for the growth of financial fragility, and financial fragility did so at an accelerated rate, as Figure 9 shows. Since 2008, financial fragility has declined dramatically as housing finance is simplified through foreclosure, house sales, and the issuance of term rate refinance and purchase mortgages at more affordable terms and with tighter underwriting standards. 
Similar trends are observed in the United States. As in the UK, financial fragility in housing funding grew from the late 1990s. Some members of the Federal Open Market Committee, namely Gramlich and Jordan, became worried about the deterioration of households' finances: "There are people making real estate investments for residential and other purposes in the expectation that prices can only go up and go up at accelerating rates. Those expectations ultimately become destabilizing to the economic system" (FOMC 1999, 123).

Gramlich was worried about predatory lending and made his views known to Greenspan, who did not consider it to be a significant problem. Greenspan seemed to be vindicated by the pause in the growth of fragility that occurred in the early 2000s because of a burst of the dotcom bubble in 2000 and a minor recession in 2001. However, from 2003, financial fragility grew very rapidly for the same reason as in the United Kingdom. Households in the United States were the first to experience a decline in financial fragility from 2007, followed by the United Kingdom and France. The decline in fragility has been the most dramatic in the US, and household fragility is almost back to its level of 2003, when most of the Ponzi financing in housing had not occurred.

Figure 8 Index of financial fragility (Base year: 1996)

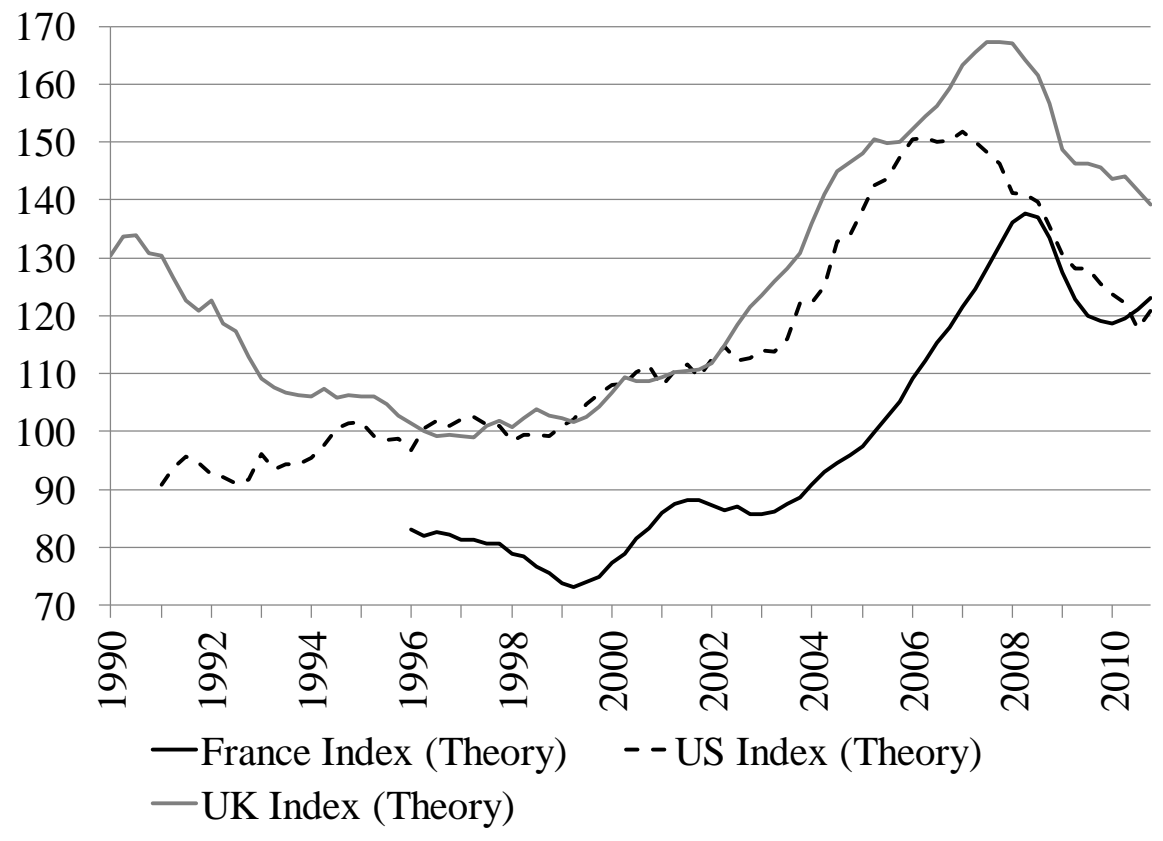


Figure 9 Two-quarter moving average of the annualized growth rate of the index

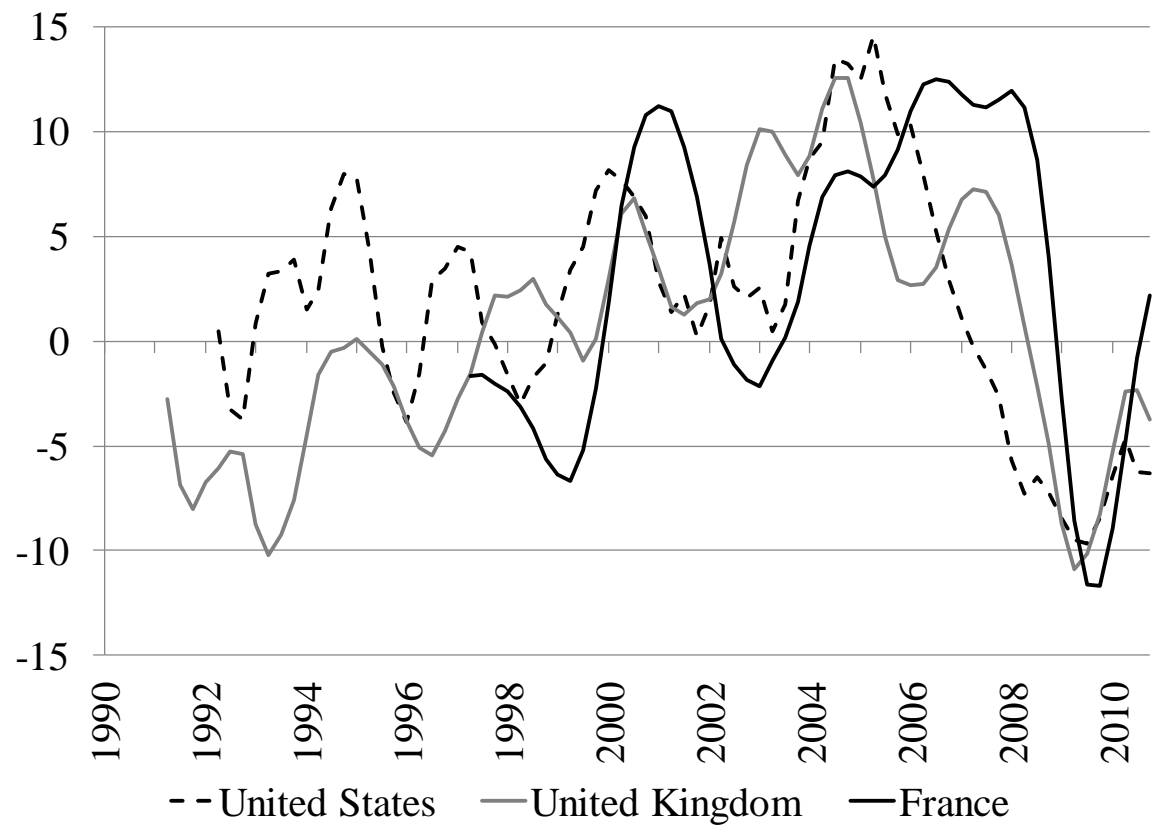

Overall, this index provides some insights into the funding methods used by households to purchase and hold a house. It shows that the decline in housing underwriting standards started at least at the end of the 1990s in the US and the UK and lasted until the second half of the 2000s. Some FOMC members in the United States were right to worry about the dangerous, albeit early, trends occurring in the housing market.

\section{EXTENDING THE ANALYSIS: COMPARING FINANCIAL FRAGILITY ACROSS COUNTRIES AND ADDING OTHER SOURCES OF RISK}

The previous index was constructed to measure the change in financial fragility in a given country relative to a given period of time. One may also want to compare financial fragility across countries. For example, Figure 2 shows that the liquidity ratio is much higher in France relative to another country so, given everything else, it must mean that the risk of debt deflation originating from French housing finance is smaller than that of the other two countries. In order to build such an index, one needs to have the same variables available across countries. Appendix 2 shows how the index is built, and Figure 10 shows the results of this procedure, which are similar to the previous index in terms of trends. As expected, Figure 10 shows that the risk of financial instability coming from French housing finance is much lower than in the United States. 
Figure 10 Financial fragility index across countries

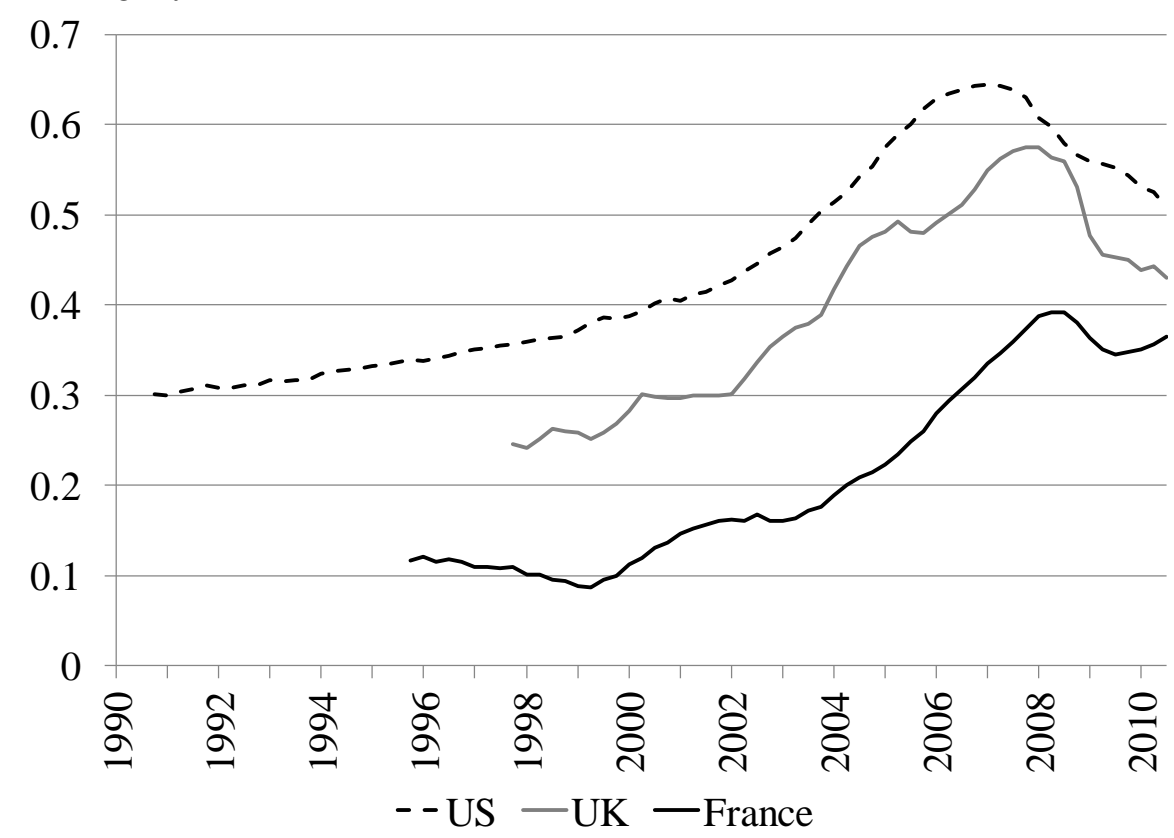

The main drawback of this procedure is that the very limited availability of homogenous data across country that represent refinancing pressures and asset-based lending. Thus, some important aspects of financial fragility cannot be captured properly for cross-country comparison.

This index has focused on the amplification risk of financial disturbances because the goal was to capture the risk of a debt deflation. While this is an important facet of debt deflation, it is not the only one because the size of a shock matters to determine the size of the amplification. Thus, some research has to be devoted to the measurement of credit risk, and there has already been plenty of work in that field. For example, Aspachs et al. (2007) use rising probability of default of households and lower bank profit to measure financial fragility and use decline in real GDP to measure financial instability. Gonzalez-Hermosillo (1999) and Demirgüç-Kunt and Detragiache (1998) note that rising non-performing loans are a sign of crisis or near bank failure. Davis (1995) defines fragility through rising default rate and foreclosure. This paper will not go further on this issue, but warns against using datasets that are strongly correlated with crises. Default, non-performing loans, and foreclosure may not be the appropriate measure of financial fragility. Indeed, all these are the manifestation of a crisis instead of a measure of fragility. As noted earlier, default rates declined in the United States during the early 2000s and were at historical low right before the crisis started. 
For the housing sector, better measures of credit risk would be the proportion of subprime mortgages, the proportion of no-doc or low-doc mortgages, and the proportion of payment-option mortgages. Unfortunately, data about these elements are extremely difficult to

get (some data is available for the United States, but it is very expensive), and so we might have to content ourselves for the moment with the variables used above.

\section{CONCLUSION}

This paper constructs an index of financial fragility based on Minsky's framework of analysis. In this approach, financial crises are endogenous occurrences induced by changes in funding practices. Thus, in order to detect financial fragility, the index focuses heavily on the means used by economic agents to service their debts.

This index is constructed for the household sector in three countries and detects how the financial practices used to fund homeownership changed overtime in a way that is conducive to a debt deflation. This helps regulators and supervisors to get an idea of the financial sustainability, or lack thereof, over a period of economic growth. Currently the focus has been mainly on credit risk, and more recently (via Basel III) liquidity risk, to assess financial instability, and this index aims at complementing that approach by focusing on amplification risk induced by default, the closing of refinancing sources, or financial disturbance. The risk of amplification is high when the main purpose of refinancing and asset liquidation is to service debts - that is, when asset-based lending instead of income-based lending becomes a common way to fund asset positions.

It is clear from the index that the growth of homeownership in the past decade was not sustainable because its funding was unsustainable. Financial supervisors and regulators should have intervened much earlier even though default rates on mortgages were very low, wealth was rising, and banks were highly profitable.

One implication for the construction of the index is that it sets a very specific research agenda. The amount of data available regarding sources of refinancing needs, debt service ratio, cash inflow sources, and cash outflow sources is currently extremely limited and that affects the quality of the index above. Some research efforts should be oriented toward improving our understanding of the funding practices of economic units. 


\section{APPENDIX 1: INDEXES WITH DIFFERENT WEIGHT STRUCTURES}

Figures A1.1 to A1.3 show the index for the United States, the United Kingdom, and France under three different weight structures, one based on theory (used in the core of the paper), one based on equal weight, and one based on a statistical method called Principal Component Analysis (PCA). One may note that all the weight structures have drawbacks, and in the end assigning weight always involves some arbitrariness (Howe et al. 2008).

Overall, the trend of the index is mostly unchanged by the weight structure, except for France when the PCA weight structure is used. For the United States, where the data is the most reliable, the structure of the weight has a very limited impact in terms of amplitude. For the other two countries, the amplitude of the index (and so its growth rate) is significantly affected by the PCA weight structure. This is especially so in France where the data about home equity lending was inferred and set at zero for the entire period, and so was given a zero weight in the PCA structure.

Table 1 Weight structures

\begin{tabular}{|c|c|c|c|c|c|c|}
\hline DATA & \multicolumn{2}{|c|}{ US } & \multicolumn{2}{c|}{ UK } & \multicolumn{2}{c|}{ France } \\
\hline $\begin{array}{c}\text { HOME EQUITY } \\
\text { LENDING }\end{array}$ & Theory & PCA & Theory & PCA & Theory & PCA \\
\hline HOUSE PRICE & 0.15 & 0.179 & 0.20 & 0.093 & 0.100 & 0.000 \\
\hline MORTGAGE TO GDP & 0.1 & 0.180 & 0.15 & 0.292 & 0.175 & 0.331 \\
\hline $\begin{array}{c}\text { MORTGAGE TO } \\
\text { MONEY }\end{array}$ & 0.2 & 0.176 & 0.25 & 0.295 & 0.275 & 0.335 \\
\hline $\begin{array}{c}\text { DEBT SERVICE } \\
\text { RATIO }\end{array}$ & 0.3 & 0.146 & 0.25 & 0.029 & 0.275 & 0.006 \\
\hline CASH OUT & 0.15 & 0.140 & & & & 1 \\
\hline TOTAL & 1 & 1 & 1 & 1 & 1 & 1 \\
\hline
\end{tabular}


Figure A1.1 United States financial fragility index in households housing funding

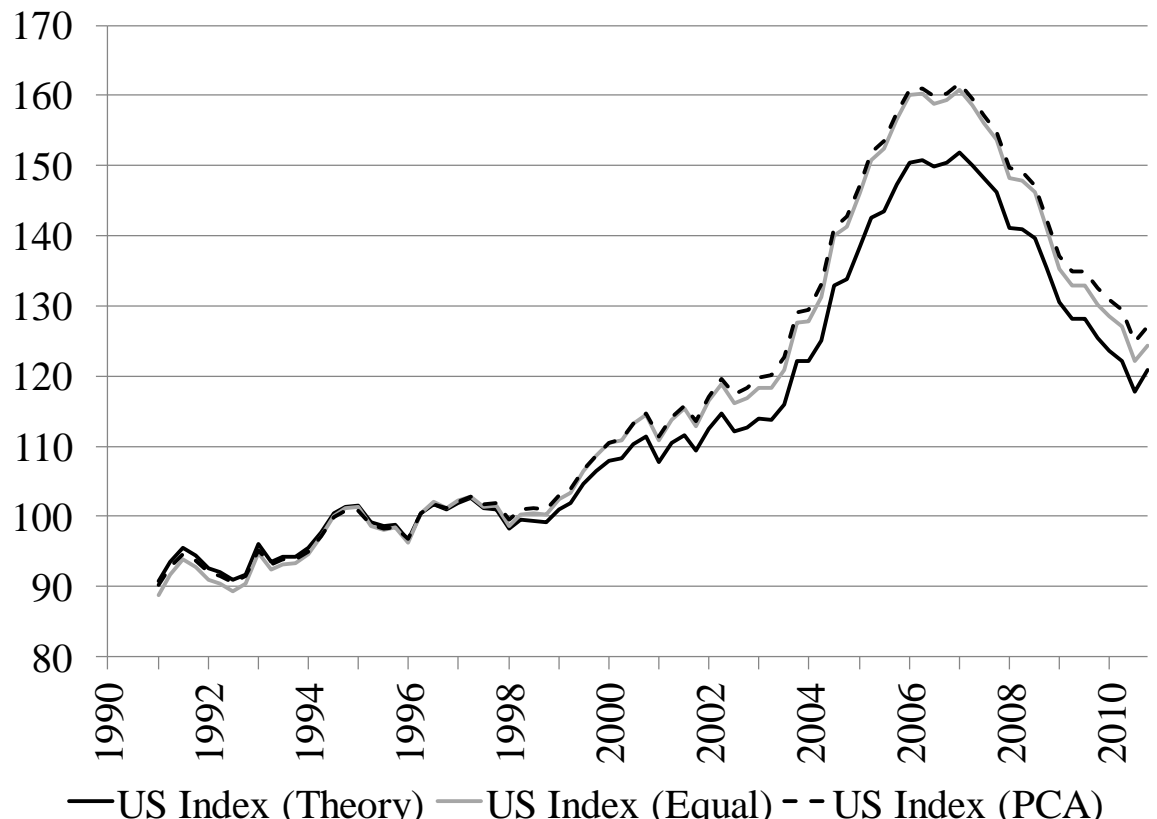

Figure A1.2 France financial fragility index in households housing funding

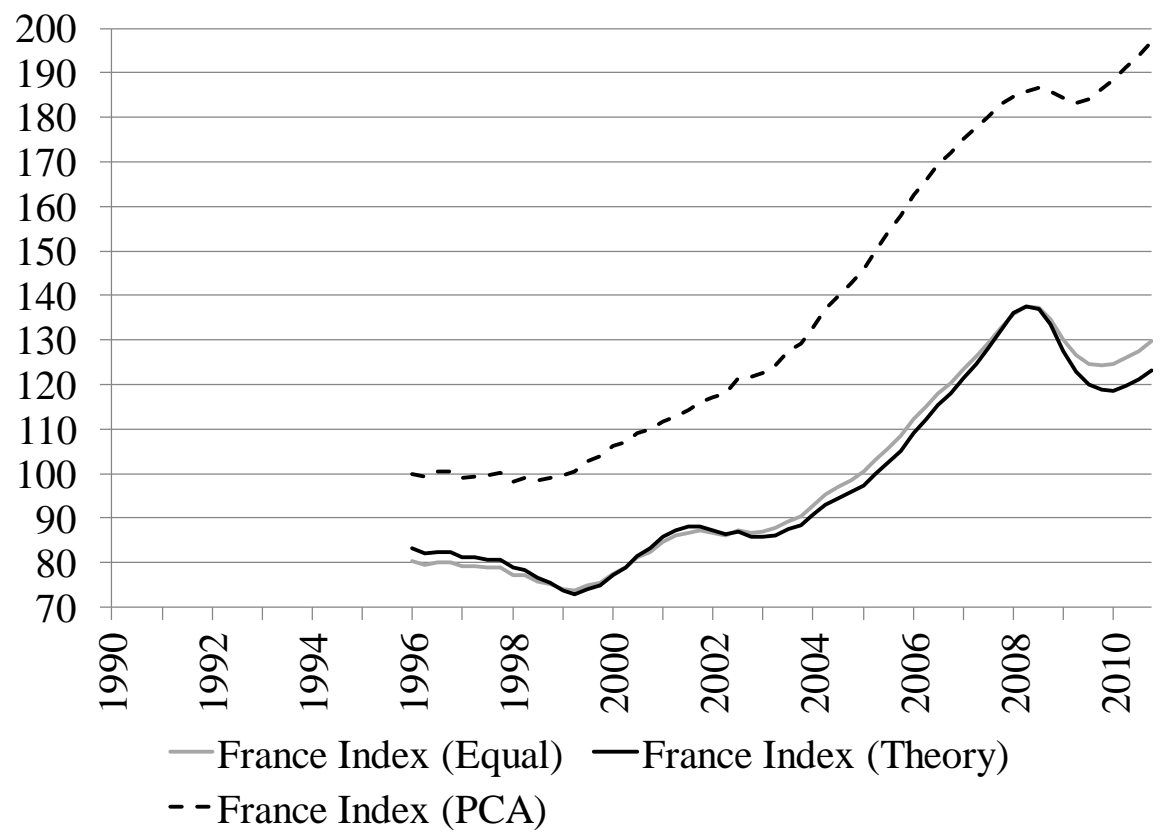


Figure A1.3 United Kingdom financial fragility index in households housing funding

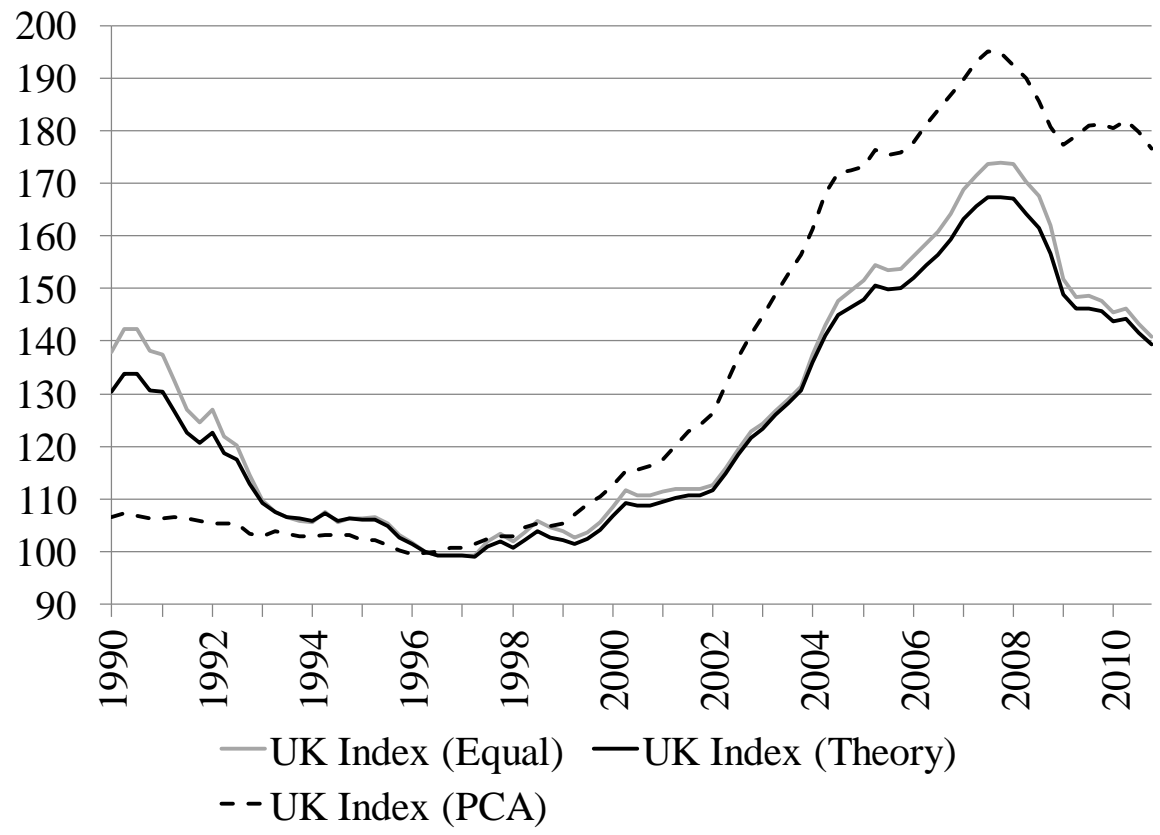




\section{APPENDIX 2: CROSS-COUNTRY INDEX}

Relatively homogenous variables that can be computed across all three countries are the house price to population ratio (P/POP), the mortgage debt to monetary asset ratio (D/M), the interest rate service ratio (ISR), the proportion of home equity loan in mortgages (HELOC) and the mortgage debt to GDP ratio (D/GDP). The HELOC dataset is set to zero for the entire period in France and is proxied in the UK by the share of the monetary value of new loans secured on dwellings for purposes other than remortgaging or purchase of homes (the dataset starts in 1997).

In order to normalize all these datasets across countries, a common procedure is to use the following formula:

$$
I_{i j}=\frac{X_{i j}-X_{i m i n}}{X_{i \max }-X_{i \min }}
$$

$X_{i j}$ is the variable $i$ for country $j, X_{i m i n}$ is the minimum value of a variable $i$ across countries, and $X_{\text {imax }}$ is the maximum value of a variable $i$ across countries. Each index is then aggregated to give the following financial fragility index in housing finance:

$$
I_{H F j}=0.3 * I_{I S R j}+0.25 * I_{D / M j}+0.175 * I_{P / P O P j}+0.175 * I_{D / G D P j}+0.1 * I_{H E L O C j}
$$

A different weight structure shifts the index curve but does not change the ranking among the three countries. 


\section{REFERENCES}

Aspachs, O., C.A.E. Goodhart, D.P. Tsomocos, and L. Zicchino. 2007. "Towards a Measure of Financial Fragility.” Annals of Finance 3 (Special Issue): 37-74.

Bell, J. 2000. "Leading Indicator Models of Banking Crises: A Critical Review.” Bank of England Financial Stability Report December: 113-129.

Black, W.K. 2009. "Those Who Forget the Regulatory Successes of the Past are Condemned to Failure." Economic \& Political Weekly 44(13): 80-86.

Davis, E.P. 1995. Debt, Financial Fragility, and Systemic Risk, 2nd edn. Oxford, UK: Oxford University Press.

Demirgüç-Kunt, A. and E. Detragiache. 1998. "The Determinants of Banking Crises in Developing and Developed Countries.” IMF Staff Papers 45(1): 81-109.

De Paula, L.F.R. and A.J. Alves, Jr. 2000. "External Financial Fragility and the 1998-1999 Brazilian Currency Crisis.” Journal of Post Keynesian Economics 22(4): 589-617.

Dynan, K., K. Johnson, and K. Pence. 2003. "Recent Changes to a Measure of U.S. Household Debt Service.” Federal Reserve Bulletin (October): 417-426.

Estenson, P.S. 1987. "Farm Debt and Financial Instability.” Journal of Economic Issues 21(2): 617-627.

Federal Deposit Insurance Corporation. 2006. "Breaking New Ground in U.S. Mortgage Lending." FDIC Outlook, Summer. Available at: http://www.fdic.gov/bank/analytical/regional/index.html

Foley, D.K. 2003. “Financial Fragility in Developing Countries.” In A. Dutt and J. Ros (eds.), Development Economics and Structuralist Macroeconomics: Essays in Honour of Lance Taylor. Cheltenham, UK: Edward Elgar, pp. 157-168.

Federal Open Market Committee. 1999. Transcripts of the Meeting of the Federal Open Market Committee, February 2-3. Available at: http://www.federalreserve.gov/monetarypolicy/files/FOMC19990203meeting.pdf

Galati, G. and R. Moessner. 2010. "Macroprudential policy - A Literature Review.” Working Paper No. 267. Amsterdam, Netherlands: De Nederlandsche Bank. 
Gonzalez-Hermosillo, B. 1999. "Developing Indicators to Provide Early Warnings of Banking Crises." Finance \& Development (June): 36-42.

Grabel, I. 2003. "Predicting Financial Crisis in Developing Economy: Astronomy or Astrology." Eastern Economic Journal 29(2): 243-58.

Howe, L.D., J.R. Hargreaves, and S.R.A. Huttly. 2008. "Issues in the Construction of Wealth Indices for the Measurement of Socio-Economic Position in Low-Income Countries." Emerging Themes in Epidemiology (5)3.

Isenberg, D. L. 1988. “Is There a Case for Minsky’s Financial Fragility Hypothesis in the 1920s?” Journal of Economic Issues 22(4): 1045-1069. . 1994. "Financial Fragility and the Great Depression: New Evidence on Credit Growth in the 1920s.” In G. A. Dymski and R. Pollin (eds.), New Perspectives in Monetary Macroeconomics: Explorations in the Tradition of Hyman P. Minsky. Ann Arbor, MI: University of Michigan Press. pp. 201-229.

Knutsen, S. and E. Lie. 2002. "Financial Fragility, Growth Strategies and Banking Failures: The Major Norwegian Banks and the Banking Crisis, 1987-92.” Business History 44(2): 88111.

Kregel, J.A. 1997. "Margins of Safety and Weight of the Argument in Generating Financial Crisis." Journal of Economic Issues 31(2): 543-548.

Lamoussière-Pouvreau, C. and E. Masset-Denèvre. 2007. "L'hypothèque rechargeable.” INC Hebdo 1437.

Minsky, H.P. 1972. "Financial Instability Revisited: The Economics of Disaster." In Board of Governors of the Federal Reserve System (ed.), Reappraisal of the Federal Reserve Discount Mechanism. Washington, DC: Board of Governors of the Federal Reserve System, pp. 95-136. . 1975. "Suggestions for a Cash Flow-Oriented Bank Examination.” In Federal Reserve Bank of Chicago (ed.), Proceedings of a Conference on Bank Structure and Competition. Chicago, IL: Federal Reserve Bank of Chicago, pp. 150-184. . 1977. "Banking and a Fragile Financial Environment." Journal of Portfolio Management (Summer): 16-22. 
. 1984. "Banking and Industry between the Two Wars: The United States." Journal of European Economic History 13 (Special Issue): 235-272.

. 1986. Stabilizing an Unstable Economy. New Haven, CT: Yale University Press.

Niggle, C.J. 1989. “The Cyclical Behavior of Corporate Financial Ratios and Minsky's Financial Instability Hypothesis.” In W. Semmler (ed.), Financial Dynamics and Business Cycles. New York, NY: M. E. Sharpe, pp. 203-220.

Reinold, K. 2011. "Housing Equity Withdrawal since the Financial Crisis.” Bank of England Quarterly Bulletin, Quarter 2: 127-133.

Schroeder, S.K. 2008. "The Underpinnings of Country Risk Assessment.” Journal of Economic Surveys 22(3): 498-535. . 2009. "Defining and Detecting Financial Fragility: New Zealand's Experience." International Journal of Social Economics 36(3): 287-307.

Seccareccia, M. 1988. "Systemic Viability and Credit Crunches: An Examination of Recent Cyclical Fluctuations.” Journal of Economic Issues 22(1): 49-77.

Sinai, A. 1976. "Credit Crunches_-An Analysis of the Postwar Experience.” In O. Eckstein (ed.), Parameters and Policies in the U.S. Economy. Amsterdam, Netherlands: NorthHolland Publishing Co., pp. 244-274.

Suzuki, Y. 2005. “Uncertainty, Financial Fragility and Monitoring: Will Basle-Type Pragmatism Resolve the Japanese Banking Crisis?” Review of Political Economy 17(1): 45-61.

Wolfson, M.H. 1994. Financial Crises, 2nd edn. Armonk, NY: M. E. Sharpe.

Wray, L.R. 2009. "The Rise and Fall of Money Manager Capitalism: A Minskyan Approach.” Cambridge Journal of Economics 33: 807-28.

Zelman, I.L. 2007. “Mortgage Liquidity du Jour: Underestimated No More.” Equity Research (March). Credit Suisse: New York. 